\title{
Discussion on the Translation and Culture of Xi' an Horticultural Exposition Material from the Point of Broadcasting
}

\author{
Zhengfeng Chen \\ Xidian University \\ Xi'an, China
}

\author{
Rong Zhao \\ Xidian University \\ Xi'an, China
}

\author{
Pei Zheng \\ Xidian University \\ Xi'an, China
}

\begin{abstract}
This paper explores that various translating strategies should be chosen flexibly under the guidance of purpose theory from the point of broadcasting and culture confidence. Besides, the effect of the international communication and the translation of Xi'an Horticultural Exposition material can be gained. Thus, the international communication and culture confidence can be achieved successfully.
\end{abstract}

Keywords-implication culture; purpose theory; culture confidence

\section{INTRODUCTION}

With the development of the economic globalization, the international communication has become the main link to promote mutual understanding and maintain the world peace. In the globalization of cultural era today, the international translation is much more important than before, so is the cultural self-confidence for Chinese. In 2017 in July, in the 95th anniversary of Chinese the Communist Party, Chinese President Xi Jinping, made a speech and asked people in China: "to adhere the self-confidence of the socialist road ,the self-confidence of the theory ,the self-confidence of socialist system and the self-confidence of culture ". Cultural self-confidence is more basic, more extensive and more profound, that is to say, cultural self-confidence is the basis of social system, socialist road, socialist theory and socialist system. Therefore, from President Xi Jinpingt's speech, it can be seen that the cultural self-confidence should be strengthened, which requires people to actively practice in cultural practice. The World Horticultural Exposition was

[Fund Project] Shaanxi Education Science Program (SGH17H050) in 2017: The Research on the Construction of O2O College English Teaching Model in the Post- MOOC Era; Xi'an Social Science Fund Project

(17Y27) in 2017: cultural confidence studies of College English teaching in Xi'an under the background of internationalization; basic scientific research business college of Xi'dian University(RW170403) in 2017and (RW170116) in 2017; the study of the spiritual and cultural needs of the Faculty from the point of cultural self-confidence of Xi'dian University union in 2017 held in Xi'an .And subsequent its international communication of World Horticultural Exposition publicity materials is a kind of historical heritage. The international influence of Xi'an can be promoted and the high consciousness and confidence of culture can be formed. To understand Xi'an economic, cultural and social development status is not enough and comprehensive by holding the World Horticultural Exposition in Xi'an under the multicultural background. Thus there is an urgent need for people to further enhance cultural awareness and actively promote cultural development. Then the high degree of cultural self-confidence and cultural self-improvement in $\mathrm{Xi}$ 'an can be strengthened. Therefore, to analyze the cultural connotation and translation of publicity materials of World Horticultural Exposition is significant to speed up the construction of an international metropolis in Xi'an this year and to show the heritage world of World Horticultural Exposition.

\section{THE TRANSLATION OF INTERNATIONAL COMMUNICATION FROM THE PERSPECTIVE OF BROADCASTING}

Lv jun (the scholar in China) believes that international translation is one of the special nature of the field. It is a branch of broadcast communication which belongs to the cross culture communication. In fact it is the essence of a kind of communication. Weber points [1] that there are five elements of the communication process: Who says what, in what channel, to whom, with What effect, this mode of transmission includes the communication subject, content, channel, object and effect etc. Later Lasswell proposes that the communication elements are corresponding to the corresponding communication subject "control analysis", corresponding to the dissemination of the contents of the "content analysis", "media channels on the corresponding analysis, corresponding to the communication object" audience analysis "and" effect and spread effect of the corresponding analysis ".The translation is the subject to the 
same constraints the above five elements. Communication studies are conducted in the same culture and in the same language, while translation is a cross-cultural communication activity [2]. Therefore, international translation is a unique mode of communication, which belongs to cross culture and inter-language communication activities. The translation information will be passed over from the perspective of communication in the translation process. The translator can pass the information to the audience with the specific channels of communication. The effect of transmission can be achieved from Chinese version into English version.

\section{THE PURPOSE THEORY OF TRANSLATION}

What new mark advocated translation strategies and methods including three aspects: text type, reader identity and the purpose of translation. Communicative translation aims to convey the information which is based on the language and culture of the target language. It is suitable for the news report, government documents and other subjects. Translation is a purposeful action for the purpose theory. Whether the translated article is successful or not depends on whether it can achieve the desired goal and certain results. To carry out the international communication, the audiences see the information at first, and then it is usually easy to accept ideas consistent with the information. Otherwise they will reject it or are unwilling to accept ideas contrary to the information [3]. When the reader sees the translated text, he will accept the information that is consistent with his original idea, that is, the original cultural context. And conversely, he will reject the inconsistent information. For the purpose of translation, communication is very clear. The first rule of translation is the purpose rule [4]. Vermeer argued that each text was produced for a specific purpose and should serve the purpose of the text in order to achieve the purpose for delivering the text. The theory does not provide the fixed translation model and technique for translators, but the expected purpose and function of the translation is the key basis for translation practice.

\section{THE TRANSLATION PRINCIPLES OF XI'AN WORLD HORTICULTURAL EXPOSITION PUBLICITY MATERIALS}

Xi'an World Horticultural Exposition publicity materials are a kind of government file, which is read by visitors from all over the world. The translation of publicity materials is especially suitable for the practical purpose theory. Therefore, the purpose theory plays a guiding role in the translation of Chinese into English. On the basis of this point, Chinese into English translation of publicity materials should be based on the translation of the text. Also the translation of publicity materials should comply with the requirements of the text in the target language [5]. The translation of Xi'an World Horticultural Exposition publicity materials is to transmit the information. The guidance of action for the purpose translation is consistent with the "theory" to achieve the objective demand for translation.

The international communication of translation is to let the world know and understand Chinese; therefore the translation should achieve its communicative function and realize the purpose of publicity. This requires the translator to understand the original material, the transformation of the original material. In order to achieve the communicative function of the language and let the audience accept the language, the translator should have the culture consciousness and adjust original material. Any publicity translation must be close to readers, which is the only way to let the audience understand text materials. In this sense, the translation of Xi'an World Horticultural Exposition publicity materials should be based on Chinese deep cultural meaning. Thus it can attract foreign tourists to visit China and understand the media related news reports .So a good Chinese image will be formed. Meanwhile, the historical and cultural heritage can be passed to the world. Cultural selfconfidence in China can also be established. In order to achieve this goal, the translator can flexibly select a variety of translation methods, such as literal translation, free translation or other methods, to achieve the target's translation.

\section{THE ANALYSIS OF TRANSLATION OF XI'AN WORLD HORTICULTURAL EXPOSITION PUBLICITY MATERIALS}

- Example One: 华夏故都, 山水之城。

The translation: An Ancient Capital, a City of Natural Beauty.

In Chinese, people often pay attention to using the words concisely and think the antithesis is a literary grace. Thus the realization of original expectations can be achieved. But for English, the description is very specific, objective, strong and very intuitive. Therefore, if one uses direct translation or mechanical dead translation, there will be lengthy sentences and the translation effect will be very poor. What is worse, the effect of attractions for readers to read the target text will be seriously damaged. In translation, the translator must adopt the method of rewriting or reorganization to retain the Chinese cultural heritage and convey the purpose of information.

- Example two: 主题园艺景点分别为长安花谷、五彩终南、 丝路花雨、海外大观和灞上彩虹; 并设有灞上人家、楖风水 岸和欧陆风情三处特色服务区。

The translation: The Five Major Horticultural Scenic Spots are the Chang'an Flower Valley, Colorful Plants from Qinling Mountains, Flowers along the Silk Road, Overseas Collections and Flower Rainbow over the Ba River. The Three Characteristic Zones refers to Romance by the Ba River, Southeast Asian Street and European Avenue.

Chinese use parallelism in the sentence .Lifelike, very detailed description of the four word phrases always can be used .This reflects the beauty and simplicity of language. So the translator, according to publicity materials as expected, abandons the Chinese form and the literal translation of four character phrases, but adopts the native speakers expression at foreigners' will and habits. This kind of translation retains the 
beauty of the language for its simplicity and conveys the information effectively.

- Example three: 西安世园会会徽取名 “长安花”, 取意 “春 风得意马蹄疾, 一日看尽长安花”。构思源于《道德经》: “道生一, 一生二, 二生三, 三生万物”, 是由三、四、 五、六边形自然花瓣组合而成的 “百花吉印”, 释义为: 三 生万物, 花开吉祥; 四合为土, 天圆地方; 五叶生木, 林森 荫育; 六流成水, 润泽万物。

The translation: The emblem of the International Horticultural Exposition Xi'an is the "Chang'an Flower", which names after a poem "Riding on the crest of success, seeing all the flowers in Chang'an." The design stems from the

Classic of the Virtue of the Path and the Power: "The Tao produced One; One produced Two; Two produced Three; and Three produced All things." The emblem takes the shape of a flower composed of petals arranged in ascending order, from the triangle of the innermost layer to the hexagon of the outer layer, forming an auspicious oriental flower seal. The emblem can be interpreted as follows: THREE for the seeds of all nature, lying in an auspicious flower; FOUR for the corners of the land, propping up the vault of heaven; FIVE for the foliage from the trees, shielding the flourishing land; And SIX for running water, nurturing all life on the planet.

In the original “长安花”, 《道德经》, the translation is not rigid translated as "Chang'an Flower", Dao De Jing. In order to achieve translation effect, the notes can be added. So it is translated as "Chang'an Flower which names after a poem", "The design stems from the Classic of the virtue of the Path and the Power". This makes readers more clearly understand Chinese culture and history. Numerals have referential and connotative meanings in Chinese. The word “万物” is an exaggeration of "more", so it is translated "all life on the planet" instead of a literal translation of Chinese four character words and symmetry.

- Example four: 设计主题: 天人长安, 创意自然

- The translation one: Theme: "Eternal peace \& harmony between nature $\&$ mankind, nurturing the future earth - a city for nature, co-existing in peace" (Chinese version: Nature and People in One in Chang'an, Nature Creativity- A City for Nature, Coexisting in Peace)

The translation two: "People" represents the city, and "Chang'an" is the ancient name of Xi'an, an ancient capital with a long history and a symbol for national prosperity and security. Hence, "Nature and People in One in Chang'an" embodies the harmonious coexistence between the city and nature. "Nature Creativity", that is "nurturing the future earth", refers to: on the basis of respecting and protecting nature, allowing nature to serve humankind by utilizing and restoring it.
The first translation takes literal translation equivalence and the target audience is Chinese, but the foreigners do not know the true charm of Chinese culture, so the translation one does not display the background and the deep cultural factors of Chinese.

In the second translation, according to the purpose, the translator reserves the actual situation of the text, deletes, adjusts and rewrites certain elements in the original text. This translation takes into account the original author, the reader, the context and other factors. It is a proper translation of the original text, which enables foreign tourists to read and understand them and thus arouses their interest. The theme of Xi'an World Horticultural Exposition is the new concept of health harmony between city and nature, which highlights the cultural value, the harmony between man and nature and advocates the new concept of low carbon and environmental protection. Therefore, when translating the text appropriately, the translator should translate the meaning of the new image of Xi'an and new concept of communication. This kind of translation can show the image of Xi'an and help Xi'an enhance international influence in the world

- Example five: 创意馆位于 2011 西安世园会主轴线上, 整个 展馆结合码头和周边场地进行设计，建筑布局呈“王”字 型, 由三翼不规则几何体组成, 青铜金属、石材及花园式种 植屋面等不同饰面的无规则衔接处理, 形成了错落有致、内 涵丰富的艺术效果。将展览展示园林园艺、植物花卉的新成 果、新产品以及环保节能新技术、新材料等。

The translation five: The Theme Pavilion, one of the four landmarks of the International Horticultural Exposition 2011 Xi'an is centrally located and was designed to be integrated with the surrounding water and land terrains. Its architectural layout is in the shape of the Chinese character “王” consisting of irregular tri-wing geometrical objects. External wall faces made of bronze, wood, or shrubbery function as irregular interfaces. The exhibition in the pavilion will showcase new achievements and products in horticulture and floriculture as well as new environmentally-friendly and energy-saving technologies and materials.

The Westerners do not understand the image of Chinese characters "王" (can directly show the Chinese architecture in Chinese eyes). If the translator just translates the literal meaning without explanations "King" meaning, foreigners cannot understand the architecture of World Horticultural Exposition. Without any doubt the effect of communication cannot be achieved. In the translation process the communicative function should be achieved as the main purpose. It is necessary to retain the national characteristics and the Chinese elements of World Horticultural Exposition publicity materials in part, but also the translator should conform to the western mode of thinking. Therefore, the meaning of "King" should be explained by using literal translation and indirect translation. This does not only 
retain the traditional Chinese culture and convey the culture, but also can achieve the effect of international communication.

\section{CONCLUSION}

From the perspective of broadcasting, the translation of international communication is the dissemination and communication activities across different cultures and is the platform to show Chinese to world, which is the bridge of cultural self-confidence and the inheritance of traditional Chinese culture. Through the analysis of translation of Xi'an World Horticultural Exposition publicity materials, the unique cultural heritage, the profound historical and cultural tradition should be translated. Thus, the charm from Chinese cultural spirit can be spread to the world, which can make people feel confident and further enhance the culture image of China. It can be seen that the translation of publicity materials is based on purpose theory. So translators should choose the realization of purpose translation strategies and methods in order to achieve the purpose of communication. Therefore, translators can adopt different translation strategies to improve the effect of communication. This will help Xi'an establish a good international image in the world and set up cultural self-confidence for people so as to enhance national cultural soft power.

\section{REFERENCES}

[1] Jun. The translation - A special field of communication [J]. foreign languages, 1997 (2): 39-43.

[2] Li Zhengliang. Communication theory [M]. Beijing: Communication University of China press, 2007:118-119.

[3] Jia Wenbo. Function of Translation [M]. Beijing: China Translation Publishing Company, 2004.

[4] Nord , C. Translation as a Purposeful Activity: Functionalist Approaches Explained.Shanghai: Shanghai Foreign Language Education Press, 2001.

[5] Newmark Peter. Approaches to Translation[M].Shanghai:Shanghai Foreign Language Education Press, 2001.

[6] Chen Hongwei, Li Yadan. New Chinese English translation course [M]. Shanghai: Shanghai foreign language education press, 2004.

[7] Expo 2011 Xi'an Editorial Office. An Overview of the Exposition Xi'an China [M].Xi'an:San Qin Publishing press, 2011.

[8] www.expo2011.cn 